\title{
LETTERS
}

\section{Carbapenem-resistant Acinetobacter baumannii carrying the NDM-1 gene, Czech Republic, 2011}

\author{
A Nemec (anemec@szu.cz) ${ }^{1}$, L Krizova ${ }^{1}$ \\ 1. Laboratory of Bacterial Genetics, Centre for Epidemiology and Microbiology, National Institute of Public Health, Prague, Czech \\ Republic
}

To the editor: We read with interest the paper of Hrabák et al. [1] on the isolation of a bla ${ }_{\mathrm{NDM}-1}$-carrying Acinetobacter baumannii strain. However, although the authors believed to be the first in the Czech Republic to report on a New Delhi metallo-beta-lactamase-1 (NDM-1)-producing bacterium, there have been other reports on the same $A$. baumannii strain in the country $[2,3]$. Here, we would like to comment on some points of these studies.

In our report published in a Czech national bulletin in September 2011 [2], we presented epidemiological and microbiological data on a high-level carbapenemresistant strain (designated ANC 4097) isolated from a patient hospitalised in an intensive care unit in the Czech Republic. Based on the available information, we concluded that the strain had been imported to the Czech Republic from Egypt in mid-2011 [2]. The strain was shown to be resistant in vitro to all beta-lactams and to most other clinically relevant antimicrobial agents, and to carry the genes encoding the NDM-1 and OXA-23 carbapenemases together with a number of other resistance determinants [2]. In a later paper, we provided additional genetic characterisation of ANC 4097 focused on the genetic structures associated with the bla $a_{\mathrm{NDM}-1}$ and bla $a_{\mathrm{OXA}-23}$ genes [3]. We have only recently learned that the laboratory where the original clinical specimens were processed had provided the same bacterial strain to two research groups. Thus, two independent investigations on the same strain were conducted leading to our papers $[2,3]$ and that of Hrabák et al. [1].

Even though the data on the NDM-1 carrying strain presented in the independent studies are mostly congruent, some findings and conclusions by Hrabák et al. [1] deserve a commentary. Firstly, Hrabák et al. claimed that the strain was a producer of the NDM-1 carbapenemase based on the presence of the $b / a_{\mathrm{NDM}-1}$ gene, carbapenemase activity, and the inhibitory effect of ethylenediaminetetraacetic acid (EDTA) on the carbapenem resistance phenotype. However, ANC 4097 was also shown by us to harbour the bla $a_{\mathrm{OXA}-23}$ and bla $a_{\mathrm{OXA} 51}$-like genes, both carrying ISAba1 in their promoter regions $[2,3]$. Therefore, the strain may produce at least three different carbapenemases, each of which can be responsible for the carbapenem resistance. As EDTA inhibition of carbapenemase activity is not a specific marker to detect the metallo-beta-lactamase production in $A$. baumannii $[4,5]$, unambiguous evidence that ANC 4097 is a genuine producer of NDM-1 (and not only a carrier of a silent $b a_{\mathrm{NDM}-1}$ gene) is still missing.

Secondly, the minimum inhibitory concentration (MIC) for chloramphenicol ( $8 \mathrm{mg} / \mathrm{L})$ reported by Hrabák et al. was surprisingly low seeing as $A$. baumannii is typically resistant to this antibiotic. In contrast, we found a chloramphenicol MIC of $\geq 256 \mu \mathrm{g} / \mathrm{mL}$ in ANC 4097 using Etest (bioMérieux), and the strain yielded a positive PCR signal for the catA1 gene encoding chloramphenicol acetyltransferase (unpublished data). It is of note that the cat $A 1$ gene is part of the $A b a R_{3}$ resistance island which, or variants of which, are commonly present in A. baumannii European clone I to which ANC 4097 belongs [3].

Finally, although Hrabák et al. [1] have reported their isolates to be susceptible only to colistin, we found that ANC 4097 was also susceptible to at least tobramycin and doxycycline $[2,3]$. Even though these antimicrobials may have limited value in the treatment of systemic Acinetobacter infections they have been recommended for consideration when defining the level of multidrug resistance in $A$. baumannii for epidemiological purposes [6].

Despite these points, the epidemiological part of the report of Hrabák et al. [1] has valuably contributed to the comprehensiveness of the information on the first bacterial strain with the bla $a_{\mathrm{NDM}-1}$ gene isolated in the Czech Republic.

\section{References}

1. Hrabák J, Štolbová $M$, Študentová V, Fridrichová $M$, Chudáčková E, Zemlickova H. NDM-1 producing Acinetobacter baumannii isolated from a patient repatriated to the 
Czech Republic from Egypt, July 2011. Euro Surveill.

2012;17(7):pii=20085. Available from: http://www.

eurosurveillance.org/ViewArticle. aspx?Articleld $=20085$

2. Nemec A, Kř́žzová L, Maixnerová M, Šmejcová A, PSA.

Multirezistentní Acinetobacter baumannii nesoucí geny pro

karbapenemázy NDM-1 a OXA-23 importovaný do Ceské

republiky. [Multidrug-resistant Acinetobacter baumannii strain carrying genes encoding carbapenemases NDM-1 and OXA-23

imported to the Czech Republic]. Zprávy CEM. 2011;20(8):2958. Czech. Available from: http://www.szu.cz/uploads/ documents/CeM/Zpravy_EM/20_2011/08_srpen/295_298.pdf

3. Krizova L, Bonnin RA, Nordmann P, Nemec A, Poirel L.

Characterization of a multidrug-resistant Acinetobacter baumannii strain carrying the blaNDM-1 and blaOXA-23 carbapenemase genes from the Czech Republic. J Antimicrob Chemother. 2012 Feb 24. [Epub ahead of print].

4. Segal H, Elisha BG. Use of Etest MBL strips for the detection of carbapenemases in Acinetobacter baumannii. J Antimicrob Chemother. 2005;56(3):598.

5. Bonnin RA, Naas T, Poirel L, Nordmann P. Phenotypical-, biochemical- and molecular-based techniques for detection of metallo- $\beta$-lactamase NDM in Acinetobacter baumannii. J Clin Microbiol. 2012 Jan 18. [Epub ahead of print].

6. Magiorakos AP, Srinivasan A, Carey RB, Carmeli Y, Falagas ME, Giske CG, et al. Multidrug-resistant, extensively drugresistant and pandrug-resistant bacteria: an international expert proposal for interim standard definitions for acquired resistance. Clin Microbiol Infect. 2012;18(3):268-81. 